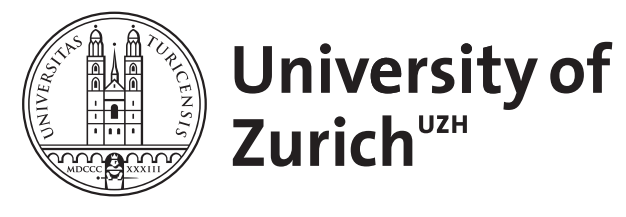

\title{
GIS-based modelling of rock-ice avalanches from Alpine permafrost areas
}

\author{
Noetzli, J ; Huggel, C ; Hoelzle, M ; Haeberli, W
}

\begin{abstract}
Changing permafrost conditions caused by present atmospheric warming are expected to affect the stability of steep rock walls in high mountain areas. The possible increase in periglacial slope instabilities and the especially long potential run-out distances in glacial environments require more awareness about the kind of events as well as robust models to foresee areas affected and distances reached. A geographic information system-based flow-routing model is introduced for modelling rock-ice avalanches on a regional scale. The model application to three major historical events in the European Alps shows the basic use for simulating such events for first-order assessments. By designating the path of steepest descent while allowing lateral spreading from the fall track up to $45^{\circ}$, general flow patterns as well as changes in the direction of progression are well reproduced. The run-out distances are determined using empirically based models and suit well the case studies presented.
\end{abstract}

DOI: https://doi.org/10.1007/s10596-005-9017-z

Posted at the Zurich Open Repository and Archive, University of Zurich

ZORA URL: https://doi.org/10.5167/uzh-62181

Journal Article

Published Version

Originally published at:

Noetzli, J; Huggel, C; Hoelzle, M; Haeberli, W (2006). GIS-based modelling of rock-ice avalanches from Alpine permafrost areas. Computational Geosciences, 10(2):161-178.

DOI: https://doi.org/10.1007/s10596-005-9017-z 


\title{
GIS-based modelling of rock-ice avalanches from Alpine permafrost areas
}

\author{
Jeannette Noetzli, Christian Huggel, Martin Hoelzle and Wilfried Haeberli \\ Glaciology and Geomorphodynamics Group, Department of Geography, University of Zurich, \\ Winterthurerstrasse 190, CH-8057 Zurich, Switzerland \\ E-mail: jnoetzli@geo.unizh.ch
}

Received 19 September 2004; accepted 4 August 2005

\begin{abstract}
Changing permafrost conditions caused by present atmospheric warming are expected to affect the stability of steep rock walls in high mountain areas. The possible increase in periglacial slope instabilities and the especially long potential run-out distances in glacial environments require more awareness about the kind of events as well as robust models to foresee areas affected and distances reached. A geographic information system-based flowrouting model is introduced for modelling rock-ice avalanches on a regional scale. The model application to three major historical events in the European Alps shows the basic use for simulating such events for first-order assessments. By designating the path of steepest descent while allowing lateral spreading from the fall track up to $45^{\circ}$, general flow patterns as well as changes in the direction of progression are well reproduced. The run-out distances are determined using empirically based models and suit well the case studies presented.
\end{abstract}

Keywords: rock-ice avalanche, rock fall, permafrost, topography-based models, hydrological flow routing, modified single-flow direction, GIS

\section{Introduction}

Rock fall represents a relevant hazard in high mountain areas that is expected to increase due to permafrost degradation caused by present atmospheric warming $[1,2]$. Warming and thawing of perennially frozen rock walls can affect their stability [3]. Rock-fall events that occur in high alpine environments may involve large volumes of material and move over long distances of several kilometres [4,5]. Combined rock-ice avalanches usually evolve from major rock falls in glacial environments that entrain large volumes of ice and snow. It is of great importance for hazard assessment to model areas possibly affected by such events and to forecast maximum distances that might be reached.

This paper presents a model to calculate the areas affected by, and the travel distance of, major rock-ice avalanches in high mountain areas. The model is imple- 
mented within a geographic information system (GIS) and is concerned with the initial broad-scale characterization of the areas potentially affected by an event from a given starting point.

When modelling mass movement processes, such as rock and ice avalanches or debris flows within a GIS environment, usually two procedures are distinguished $[6,7]$. The first identifies potential source areas for a specific hazardous process in a region of interest, and the second simulates the run-out paths and distances. Corresponding models for the first process were presented by various authors for different kinds of hazard events [8-10]. At present, however, no such model exists to determine the disposition and initiation zones for rock-fall hazards from permafrost slopes as the knowledge on the conditions under which such instabilities develop still remains very limited [1,11]. The most important processes governing the stability of perennially frozen rock walls as related to permafrost degradation are briefly outlined in the following section. For the model presented, potential rock fall source areas must be defined by the user.

In this study, a model for the second procedure is presented. It is further subclassified into a trajectory model part and a confinement model part. The former determines the fall track and the affected areas and involves flow-routing algorithms. The latter calculates the travel distance and stops the simulated movement on its path. It is based on data of around 30 historical events that occurred in glacial environments around the world. The model is then applied to three events and evaluated for modelling and first-order assessment of hazard potentials on a regional scale (corresponding to a hazard-indication map in Switzerland, covering an area of about $5 \times$ $10^{1}$ to $1 \times 10^{4} \mathrm{~km}^{2}$ ). All of the three events - Triolet 1717 , Fletschhorn 1901 and Brenva 1997 (figure 1 and table 1) - had a run-out distance of several kilometres and

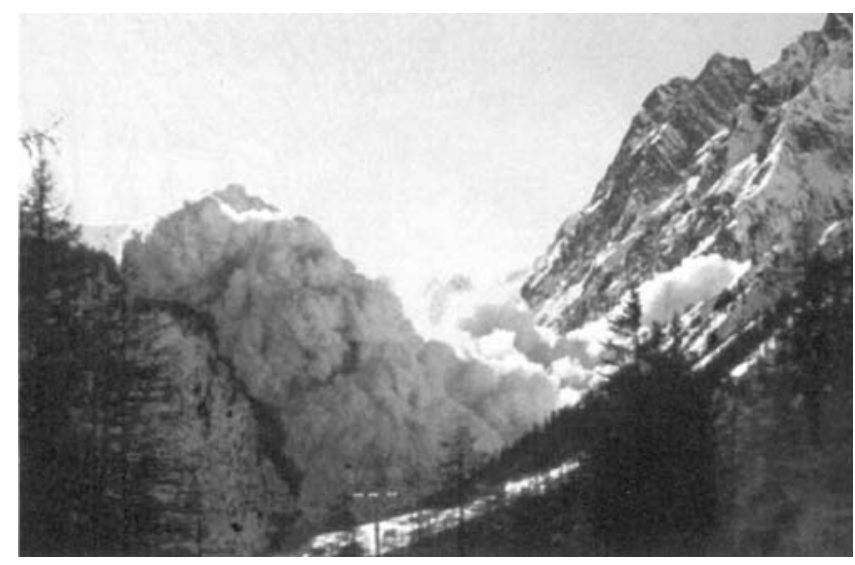

Figure 1. The rock-ice avalanche from the Brenva spur in 1997 in the Aosta Valley seen from near the entrance of Mont Blanc tunnel. The falling rock mobilized large volumes of ice and snow forming a powder avalanche that run up the opposite valley side. Photograph taken by M. Fonte on January 18, 1997. 
Table 1

Key parameters of the rock-ice avalanches presented in the case studies.

\begin{tabular}{lllllllll}
\hline No. & Name, location & Year & $\begin{array}{l}\text { Elevation } \\
(\mathrm{m} \text { asl })\end{array}$ & $\begin{array}{l}\text { Volume } \\
\left(10^{6} \mathrm{~m}^{3}\right)\end{array}$ & $\Delta H(\mathrm{~m})$ & $\Delta L(\mathrm{~m})$ & $\begin{array}{l}\text { Angle of } \\
\text { reach }\left(^{\circ}\right)\end{array}$ & Reference \\
\hline 1 & Triolet Glacier & 1717 & 3600 & $16-20$ & 1860 & 7200 & 14.5 & {$[12,13]$} \\
2 & Fletschhorn & 1901 & 3780 & 0.5 & 2300 & 6200 & 20.3 & {$[15,44]$} \\
3 & Brenva & 1997 & 3725 & $6-7$ & 2150 & 5500 & 21.6 & {$[4,16]$} \\
\hline
\end{tabular}

are among the larger events that have occurred in the permafrost altitudinal belt of the European Alps over the past centuries [11]. All three caused major damage and are well documented in the scientific literature [4,12-16].

\section{Rock fall from permafrost areas}

Permafrost is a temperature phenomenon defined as lithosphere material that remains at or below $0^{\circ} \mathrm{C}$ continuously for more than 1 year [17]. A substantial part of the permafrost area can be characterized as alpine permafrost, which is located in high mountain environments. Over the past century, permafrost in the European Alps is likely to have warmed by $0.5-0.8^{\circ} \mathrm{C}$ in the top layers [18]. Besides other factors promoting rock fall [19], such as weathering [20], geotechnical properties of the bedrock material and slope morphology, changing permafrost conditions caused by present atmospheric warming influence the stability of steep rock faces in high mountain areas. A higher frequency of rock falls could be one of the consequences [1-3].

The thermal response of permafrost to atmospheric warming [1,2,21] generally takes place at different scales of time and depth, which correspond to frequency and magnitude of a possibly resulting destabilization (figure 2). Following increases in mean annual air temperature, with a delay of only months or years (direct response), the active layer thickens, and thus, new volumes of rock will be subject to critical temperature ranges or thaw. This fast and immediate response has been observed in the hot summer of 2003 [22], where exceptional rock-fall activity took place in the European Alps [3]. As a delayed response, the temperature profile within the permafrost becomes disturbed, and the lower permafrost boundary at up to hundred metres depth will rise (final response), both possibly causing large and deep-seated instabilities delayed by decades or centuries. The three events described in this paper may be related to such deep-reaching and long-term changes of the thermal conditions of the subsurface.

The stability of ice-bonded discontinuities in perennially frozen rock walls is strongly influenced by the thermal regime and may be reduced due to melting of icefilled rock joints and subsequent built up of water pressure [1]. Additionally, it has been shown in a series of direct shear box tests that a rise in ground temperature may 


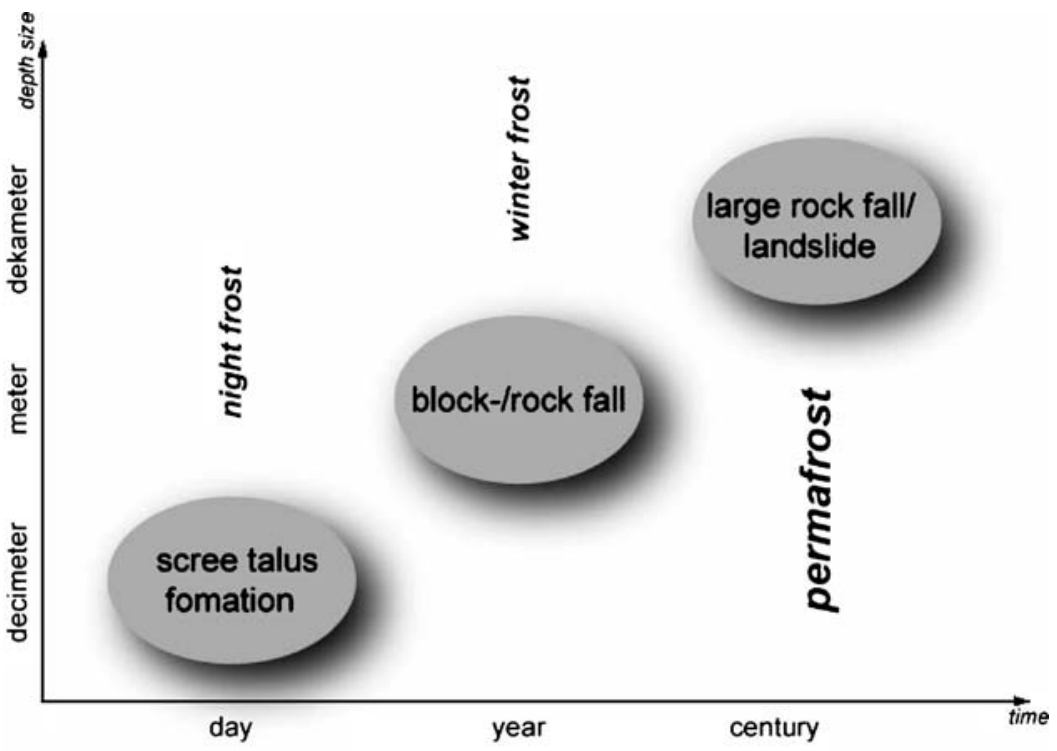

Figure 2. Time and depth scales involved in slope stabilities in high mountain areas.

lead to a reduction in the shear strength of ice-bonded discontinuities and an associated reduction in the factor of safety of the slope, which could result in slope failure even while there is still ice in the joints at temperatures just below $0^{\circ} \mathrm{C}$ [23]. Therefore, slope stability might be very sensitive to changes in the thermal environment, especially where unfrozen water is present in partially ice-filled bedrock fissures [23,24]. Instabilities are, hence, expected to concentrate in warm permafrost areas. A study on the starting zones of rock-fall events that occurred in the European Alps over the 20th century corroborates these findings [11]. Transfer to the natural environment requires knowledge about the spatial and temporal distribution of rock temperatures and their evolution. To provide a basis for assessing the impact of climatic change on rock-wall stability, understanding and modelling of the processes that determine rock temperatures are crucial $[3,25,26]$. Although permafrost thaw may affect rock walls equally or even more rapidly than debris-covered slopes, and consequences as regards natural hazards may be as or even more serious, the influence of permafrost thaw on the stability of rock faces is still a very young field of research.

Mass movements such as rock-ice avalanches can have considerably longer travel distances in glacial than in non-glacial environments due to possible interactions with and transformations of ice, snow and water [5,27]. The mobility of rock falls in glacial environments has been observed to increase by about $25 \%$ [4,5] compared to non-glacial environments. The run-out distance is enhanced due to rock-ice interactions involving (1) travel on low friction surfaces (i.e., ice and snow), (2) generation of increased pore pressures at the base of the debris by frictional heating, (3) fluidization of the debris by melting of included or subjacent ice and snow and (4) 
channelling or air launching of the debris by neoglacial moraines [5]. For example, in the Fletschhorn event in 1901 [15] or the Dzhimarai-Khokh rock-ice avalanche in the Kazbek massif in 2002 [28-30], the length of the run-out zone was significantly enlarged by such processes.

\section{Model}

\subsection{Model input data}

A confined area identifying the starting zone, represented in a grid mask, and a gridded digital elevation model (DEM) are necessary as input data for the model. Gridded DEMs were chosen because of their wide availability and use. For the case study of Fletschhorn, a 25-m gridded DEM was applied (DHM25 Level 2, Swiss Federal Office of Topography [31]); for the two other events, DEMs have been generated from contours and reference points digitized from maps. For use in the model, the DEM was corrected for possible sinks (fill algorithm according to [32]) that would cause inconsistencies in the calculation of flow directions.

\subsection{Trajectory model part}

A rock-ice avalanche is considered here as a mass moving downslope largely controlled by gravitational force and following the given topography. The flow-routing algorithm used was originally developed for debris flow-type mass movements from glacierized areas [33]. Flow-routing algorithms transfer flow sequentially to lower points or areas and determine the way in which the outflow for a given element or cell will be distributed according to mathematical equations representing processes [34]. A variety of flow-routing algorithms have been proposed, and theoretical advantages and disadvantages for different applications have been discussed [34-36]. Similar GIS models that take into account flow volume have been developed for lahars (volcanic debris flows) [37].

One of the earliest and simplest routing methods for specifying flow directions is to assign flow from each cell to one of its eight neighbours, either adjacent or diagonal, in the direction of the steepest descent. This method, designated D-8 (eight possible flow directions) [38], is still one of the most frequently used [32,39]. It is further implemented in the GIS software Arc/Info (Environmental Systems Research Institute) as a standard for hydrological flow modelling [32].

The basic concept is to simulate the path of the avalanche downslope from the point of initiation. The central flow line of the avalanche is assumed to follow the direction of the steepest descent as calculated by the single-flow direction algorithm. However, rock-ice avalanches usually deviate from the direction of the steepest descent by lateral spreading (diverging flow), which a single-flow direction path cannot model. For this reason, we have incorporated the spreading function $F_{\mathrm{d}}$ into the model, 
enabling diversion of the flow from the steepest descent of up to $45^{\circ}$ on both sides (figure 3). The model is thus capable of simulating better the different characteristics of avalanches in confined channel sections (largely limited spread due to converging flow) and on relatively flat or convex terrain (greater spread due to more diverging flow).

Once the areas potentially affected by the rock-ice avalanche are determined, the function $P_{\text {qual }}(i)$ describes a relative likelihood of the cells for being affected. $P_{\text {qual }}(i)$ is related to the flow resistance function $F_{\mathrm{r}}(i)$ and the horizontal distance $H(i)$ from a cell $(i)$ to the avalanche starting zone. $F_{\mathrm{r}}(i)$ yields a cell value that increases down valley from the location of avalanche initiation (increasing distance) and laterally in an angle of $45^{\circ}$ from the steepest descent flow path (increasing flow resistance). Hence, the more the flow diverts from the steepest descent direction and the source area, the greater the resistance is and the larger the value of $F_{\mathrm{r}}(i)$. The ratio between $F_{\mathrm{r}}(i)$ and the horizontal distance $H(i)$ from each cell $(i)$ to the avalanche starting zone is interpreted as a function describing the likelihood of each cell being affected by the avalanche [33]:

$$
P_{\text {qual }}(i)=H(i) / F_{\mathrm{r}}(i)
$$

$P_{\text {qual }}(i)$ can also be interpreted in a way of qualitative probability (e.g., colour-coded graphics).

\subsection{Confinement model part}

The trajectory model part as described above continues with the determination of the rock-fall path until a stop condition is fulfilled.

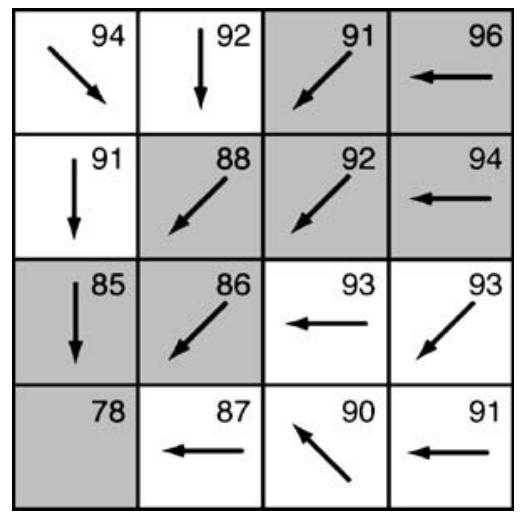

Figure 3. The flow-model approach exemplified on a hypothetical DEM subset with elevation values. General flow is from upper right to lower left. Arrows indicate the direction of flow as calculated according to the modified single-flow direction algorithm. Shaded cells show areas that are affected by an avalanche according to the flow model. 
Heim [40] introduced the empirical concept of the angle of reach $\alpha$ (also called overall slope or Fahrböschung) as a characteristic value for the run-out distance of mass movements such as rock falls and landslides. This concept describes the slope of the connecting line between the uppermost point of the scarp and the lowest point of the deposition zone. It is important that this line follows the fall track. The angle of reach is defined as the ratio of vertical $(\Delta H)$ to horizontal $(\Delta L)$ displacement:

$$
\tan \alpha=\Delta H / \Delta L
$$

Despite the simplification involved in the approach, the angle of reach is still widely used [41-43]. The application is straightforward and is especially useful for first estimations of the run-out distance of mass movement processes [27,42].

Hazard maps are often related to the farthest reach of a potentially dangerous mass. Hence, for worst-case estimates, a minimum angle of reach can be found empirically and then applied to derive maximum travel distances [44]. The minimum angle of reach known for rock avalanches in Alpine glacial environments is $14^{\circ}$ found in the Triolet event in 1717 [11]. Larger rock avalanches in the European Alps usually travelled distances equivalent to a minimum angle of reach of about $20^{\circ}$ (e.g., Fletschhorn,

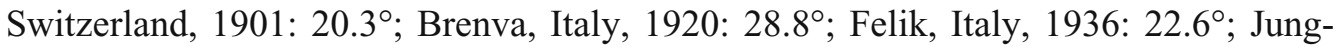
frau, Switzerland, 1937: 19.9॰; Becca de Leseney, Italy, 1952: 23.5; Brenva, Italy, 1997: $21.6^{\circ}$ ) [11]. In areas outside Europe, smaller values have been observed [5].

It has been demonstrated that the angle of reach is dependent on the volume of the moving mass [41, 45-47]. Hence, if the volume involved is known or can be estimated, the travel distance can be determined more accurately. Evans and Clague [5] describe the statistical relation between volume and angle of reach for events located in glacial environments as an inverse logarithmic correlation:

$$
\log (\tan \alpha)=0.140-0.106 \log V
$$

It has been found for cases in the Italian Aosta Valley that equation (3) is best suited [48]. For application in this study, the statistical relation has been extended by several events in the Alps travelling over glacier surfaces [11] and recalculated (figure 4). The following best-fit logarithmic regression was obtained:

$$
\log (\tan \alpha)=0.165-0.103 \log V
$$

The regression coefficient $r$ could be improved from -0.491 to -0.617 for the new model. Although the scatter is rather high and the sample is still small, the $r$ value is similar to that in relations published previously [41]. Some of the events included in the Evans and Clague formula (3) and with it in equation (4) show larger volumes and comparably lower angle of reach than the events observed in the Alps (figure 4). This is partly because some of these events involve processes such as fluidization and/or transformation into debris or mudflow (e.g., Huascaràn, Peru, 1962 and 1970 [49]), which have seldom been documented in the Alps. 


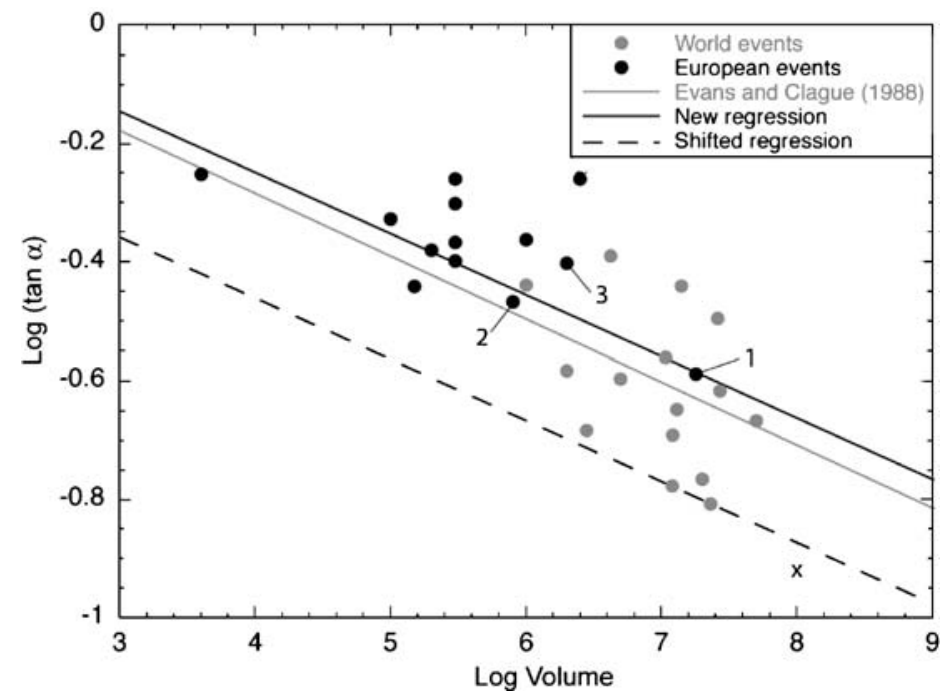

Figure 4. Angle of reach $(\tan \alpha) v s$. volume for rock-fall events in glacial environments. Events located in the Alps [11] are represented by black points; events outside Europe [4] are represented by grey points. The dashed line corresponds to a shift of the new model to the outermost point and represents an empirically deduced worst-case scenario. Numbers refer to those in table 1 . The cross marks the position of the Dzhimarai-Khokh event in the Russian Caucasus. This event is not included in the model.

It must be emphasized that the model from equation (4) represents an empirical mean rather than maximum possible run-out distance. For calculating the maximum possible length of the run-out zone based on the documented events, the regression line can be shifted through the event showing the longest run-out distance in relation to volume (figure 4):

$$
\log (\tan \alpha)=-0.040-0.103 \log V
$$

\section{Model application and results}

\section{Case study 1: Triolet 1717}

On the night of September 12, 1717, a large mass of ice-clad granite rock fell from warm permafrost $\left(0\right.$ to $\left.-5^{\circ} \mathrm{C}\right)$ [11] in the crest of the Mont Blanc massif at around $3600 \mathrm{~m}$ asl (Aiguille de l'Eboulement) onto Triolet Glacier in the upper Aosta Valley, Northwest Italy, and moved rapidly into Ferret Valley where it buried two small settlements, killing two inhabitants and their cattle [12,13] (figure 5). The shattered rock mass descended $1860 \mathrm{~m}$ along a horizontal distance of around $5000 \mathrm{~m}$ over the glacier and continued another $2000 \mathrm{~m}$ on the valley floor. With a total 


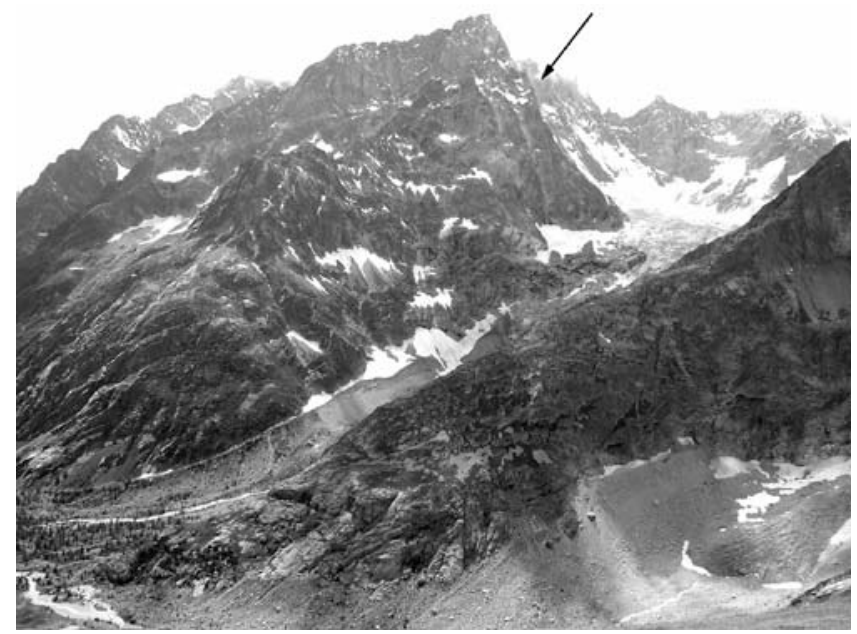

Figure 5. Oblique perspective view of the run-out area of the Triolet event with parts of the Triolet Glacier in the upper right. The arrow points at the starting area of the 1717 rock avalanche. Photograph taken by Ch. Huggel on July 10, 2004.

horizontal travel distance of $7200 \mathrm{~m}$ and its angle of reach of $14.5^{\circ}$, this is the largest run-out distance of a historically documented rock avalanche in the European Alps [11]. The accumulation volume has been estimated to 16 to $20 \times 10^{6} \mathrm{~m}^{3}$ and, for a long time, was considered to be a glacial deposit [13].

The affected areas modelled correspond to the outlines of the 1717 event (figure 6). The general path and the strong deflection to the right in the middle of the run-out zone as well as the flow diversion are reproduced well. The left lateral areas not modelled in the strong bend are caused by upward flow due to the superelevation of the avalanche in this part. Only at the end of the run-out zone the modelled avalanche width becomes too narrow due to the DEM used. According to equation (4) and based on a volume of $20 \times 10^{6} \mathrm{~m}^{3}$, the simulated movement was stopped at an angle of reach of $14.5^{\circ}$. Implementing equation (5) for worst-case scenarios would overestimate the travel distance of the 1717 event by more than $2 \mathrm{~km}$.

\section{Case study 2: Fletschhorn 1901}

The rock-ice avalanche with the longest known run-out distance in the Swiss Alps occurred on March 19, 1901 in the Valais Alps [15,44]. A $3 \times 10^{5} \mathrm{~m}^{3}$ rock mass detached from cold permafrost $\left(-5\right.$ to $\left.-10^{\circ} \mathrm{C}\right)$ [11] in the north-east flank of the Fletschhorn at $3780 \mathrm{~m}$ asl, carried away $5 \times 10^{5} \mathrm{~m}^{3}$ of the overlying glacier and descended onto Rossboden Glacier. On its way, it was channelled by the glacier's lateral moraines, incorporated about 3 to $5 \times 10^{6} \mathrm{~m}^{3}$ of snow and produced 


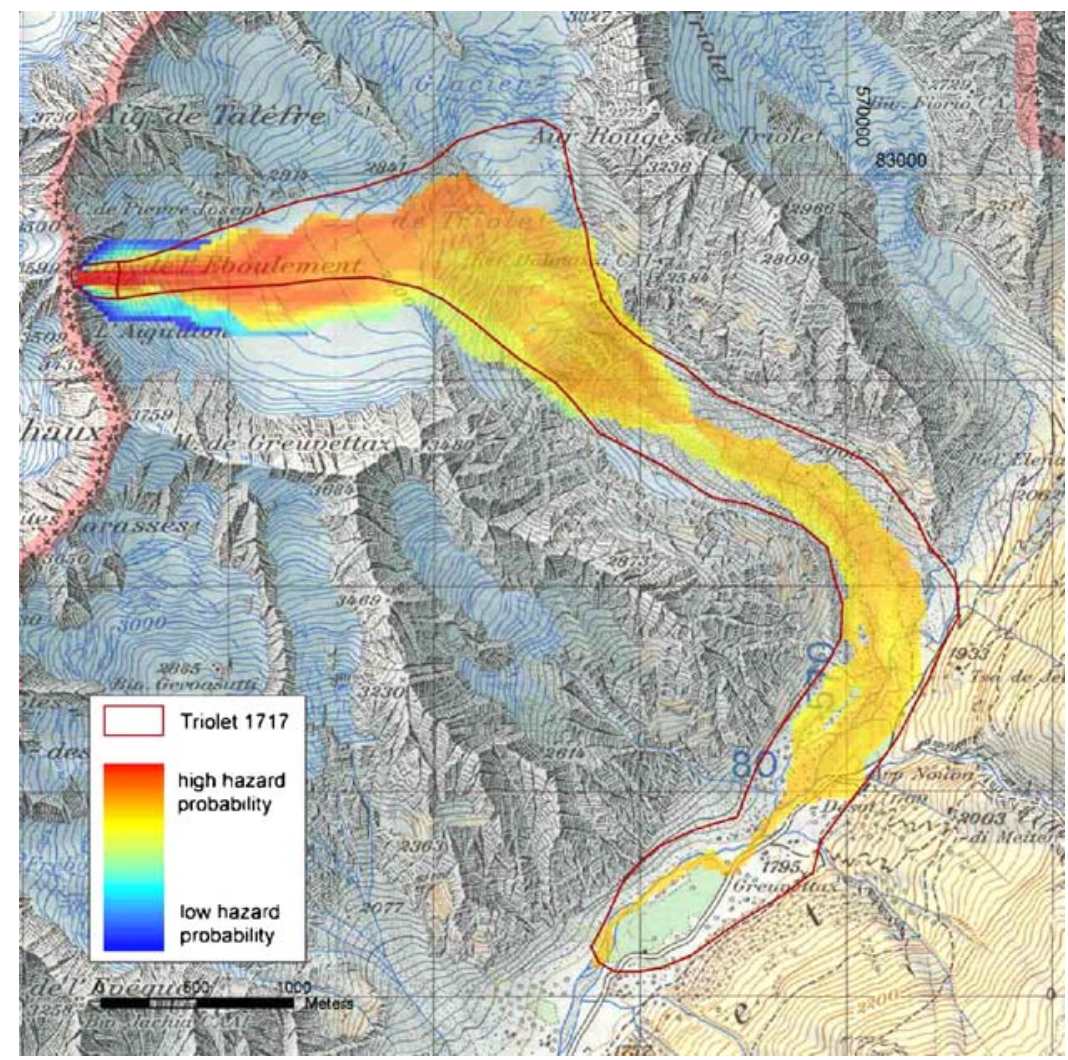

Figure 6. Affected areas modelled for the Triolet event. In red are the outlines of the rock-ice avalanche in 1717. Map (C) swisstopo (BA056938).

an air blast in the Simplon Valley that destroyed forests and pasture and killed two herdsmen and their cattle. Eventually, the avalanche stopped some $100 \mathrm{~m}$ before it reached the village of Simplon. About halfway down, one lobe overflowed the left lateral moraine and produced a major jump through the air. The total horizontal run-out was approximately $6200 \mathrm{~m}$ with a total drop height of $2300 \mathrm{~m}$; the angle of reach was $20.3^{\circ}$.

The fall track as well as the lateral spreading modelled coincides well with the areas affected by the 1901 rock-ice avalanche (figure 7). The reproduced avalanche correctly deflects to the right when entering the main valley and represents well the spreading of the debris mass. However, the overflow over the left lateral moraine in 1901 cannot be reproduced using this approach, as the model does not simulate run-up. The run-out distance is overestimated by a maximum of $1 \mathrm{~km}$ using an angle of reach of $16.5^{\circ}$ according to equation (4) and a volume of $4 \times 10^{6} \mathrm{~m}^{3}$. Equation (5) models a travel distance that is far too long compared to the historical event. 


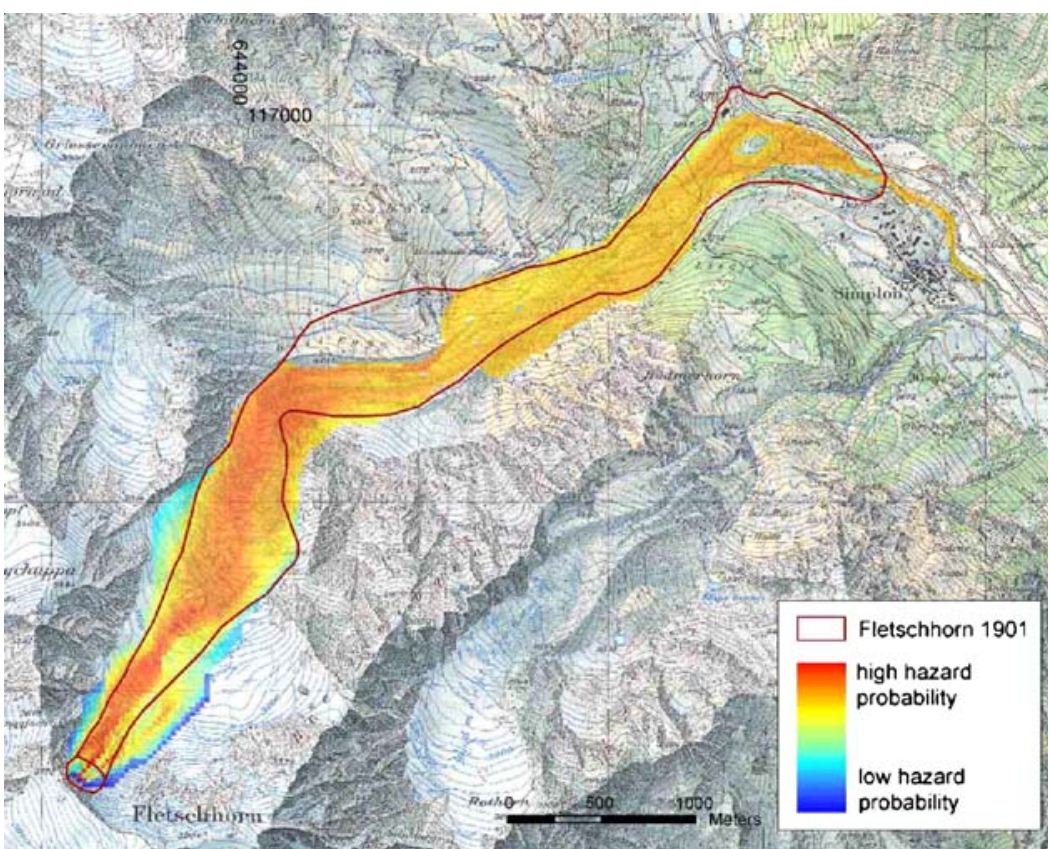

Figure 7. Affected areas modelled for the Fletschhorn event. In red are the outlines of the rock-ice avalanche in 1901. Map and DHM25 (C) 2005 swisstopo (BA056938).

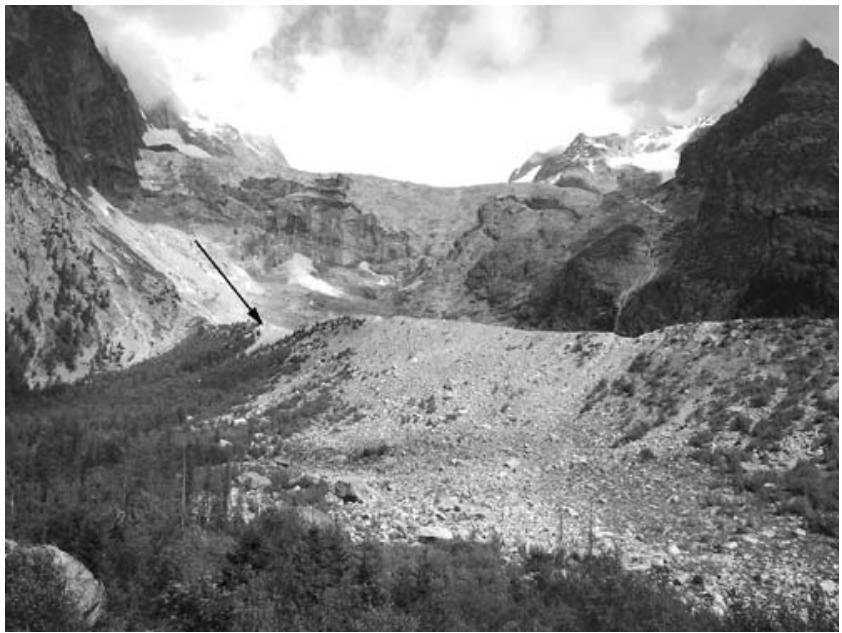

Figure 8. Right lateral moraine of the Brenva Glacier with the breach caused by the rock avalanche in 1997. Photograph taken by Ch. Huggel on July 11, 2004. 


\section{Case study 3: Brenva 1997}

A recent major event in the Alps occurred on January 18, 1997 in the upper Aosta Valley, when a large mass of granite rock $\left(2\right.$ to $\left.3 \times 10^{6} \mathrm{~m}^{3}\right)$ detached from warm permafrost $\left(0\right.$ to $\left.-5^{\circ} \mathrm{C}\right)$ [11] in the Mont Blanc east flank at $3725 \mathrm{~m}$ asl and slid downward onto Brenva Glacier (figure 1). The mass movement mobilized a large volume of ice and snow forming a powder avalanche of a total volume of 6 to $7 \times 10^{6} \mathrm{~m}^{3}[4,16]$. The horizontal and vertical displacements were 5500 and $2150 \mathrm{~m}$, respectively, and the angle of reach was $21.6^{\circ}$. One lobe of the rock-ice avalanche overflowed the right lateral moraine (figure 8 ). The other part was channelled by the right lateral moraine and reached the glacier front. On the opposite valley side, trees were thrown down by the air blast, and two skiers were killed.

This was the second time during the 20th century that the Brenva Glacier experienced the impact of a large rock-ice avalanche. On the afternoon of November 14, 1920, a similar rock fall detached from the east face of the Mont Blanc at Grand Pillier d'Angle, close to the 1997 scar, descended down the Brenva Glacier on a similar track for about $5000 \mathrm{~m}$ and run up the opposite valley side [5].

The affected areas modelled qualitatively correspond well to the Brenva event of 1997. The wide lateral spreading in the middle stems from the convex morphology of

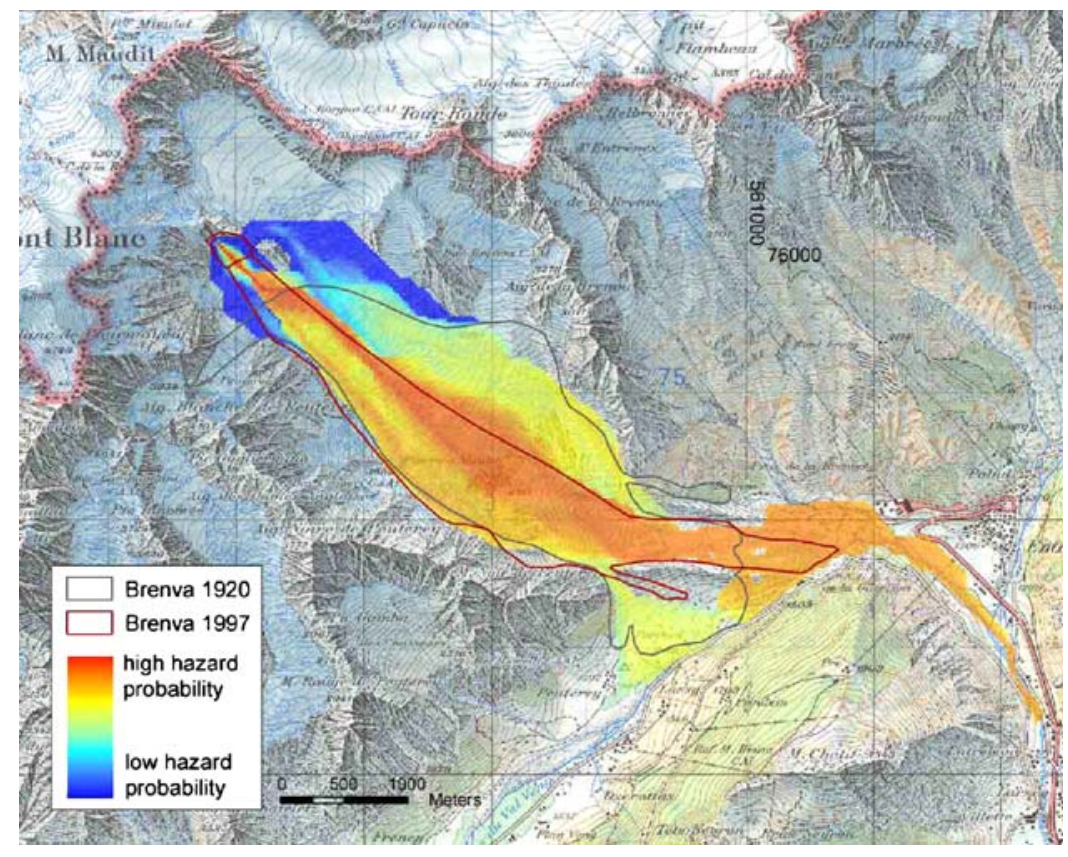

Figure 9. Affected areas modelled for the Brenva 1997 event. In red are the outlines of the rock-ice avalanche in 1997; in dark grey are the outlines of the 1920 event. Map (C) swisstopo (BA056938). 
the glacier. However, the related probabilities show that the margins of the area covered by the model in this section are less likely to be affected by a rock avalanche (figure 9). Furthermore, the modelled spread is in close agreement with the flow of the earlier event in 1920, which did not become channelled but spread over the entire Brenva Glacier instead. The run-out length has been overestimated by around $2.5 \mathrm{~km}$ using an angle of reach of $16.5^{\circ}$ according to equation (4) and based on a total volume of $6.5 \times 10^{6} \mathrm{~m}^{3}$. As what happened in the other two cases, the worst-case scenario related to equation (5) reproduces a travel distance several kilometres longer than the one observed.

\section{Discussion}

In contrast to simple single-flow direction models, the lateral spread of the rockice avalanches can be reproduced well with the model presented. However, as can be shown in the Fletschhorn study, overflow of moraines or opposite wall obstruction (e.g., the Val Pola event in 1987 [50]) is not simulated. This is due to the restriction of the model to downward motion that is controlled by gravitational force and follows the topography of the DEM. This fact has to be kept in mind when interpreting model results. Nevertheless, the degree of this obvious simplification, which ignores the full range of energy exchange relevant for avalanche motion (involving friction, momentum, etc.), is regarded feasible for first-order regional modelling and assessment. The good overall correspondence between the observed paths and the results of a topography-based flow model follows from the fact that the flow behaviour of large rock-ice avalanches is largely controlled by topography.

The volume is a second important parameter influencing the extent of areas affected. The trajectory model part presented assumes a maximum volume for defining the areas affected by the avalanche, whereas the confinement model part is based on the observed volumes of the case studies.

If the model overestimates the spread of the moving mass, the related likelihood may help define the most likely avalanche path. This function can put exaggerated spread of the falling mass, which is often the case for events involving less than the maximum volume, into perspective.

Dealing with the complete modelling procedure within a GIS environment facilitates model handling and application. The implementation of the D-8 algorithm in a frequently used software system is one of the reasons why we chose this method, since it greatly eases the application and reproduction of the model. The increase in computational effort for a method capable of modelling more possible flow directions, e.g., the D-16 method [7], does not outweigh the benefit gained by the less restricted path calculation. Applying a finer gridded DEM can compensate for the effects gained from flow direction methods using more than eight possible directions (scale effects). The use of a 25-m gridded DEM based on digitizing of map contours and reference points is qualified for modelling of major rock-ice avalanches on a regional scale. The 
main morphological structures influencing the avalanche flow behaviour (e.g., moraines, channels, convex/concave terrain morphology) are represented in such DEMs. However, smaller rock-fall events might react more sensitively to smaller morphological structures than major rock avalanches. Hence, for use of this model with smaller events, a 25-m DEM of enhanced quality (e.g., DHM25 Level 2 [31]) is required. Such high-quality DEMs have been found feasible for use in first-order assessments for debris flow with the modified single-flow directions approach [33]. For the application of more sophisticated models of flow behaviour, even such DEMs have limitations in providing the necessary details on flow and surface characteristics in the run-out zone. For these models, a 10- or 5-m DEM may be used.

The slight overestimation of the travel distance in two case studies applying regression equation (4) can be looked at as precautionary and useful for land-use planning purposes. The considerable overestimation of the modelled run-out length of the Brenva event may be explained by the energy loss of the moving mass due to the run-up on the opposite valley side. On the other hand, this means that events such as the Brenva event, although large, cannot be considered maximum or extreme events, as the models applied suggest. Scenarios simulated with the shifted regression model may be considered only for extreme events with particularly adverse conditions (e.g., flow transformation to mud/debris flow as in the 1987 event in Estero Parraguirre, Chile [51]). In fact, in areas outside the European Alps, rock-ice avalanches have reached remarkably higher travel distances. That some of these were included in regression equation (4) may explain the slight overestimation of the modelled run-out lengths. The rock-ice avalanche at Dzhimarai-Khokh in the Caucasus mentioned above travelled around $18 \mathrm{~km}$ to the entrance of the Genaldon gorge with a respective vertical displacement of $3 \mathrm{~km}[28,52]$ corresponding to an angle of reach of $9.5^{\circ}$. When considering the total volume of $100 \times 10^{6} \mathrm{~m}^{3}$ (rock and glacier), an angle of reach of $7.6^{\circ}$ is obtained by equation (5). Part of the total avalanche mass then continued as a mudflow for another $15 \mathrm{~km}$ down valley. The dimension of the proportion of volume and angle of reach of this event, hence, corresponds to the most far-reaching events of the past (figure 4). Prevalently, it is very difficult, if not impossible, to obtain a valuable estimate of the mass volume involved in a rock avalanche in advance, particularly in wintertime when large amounts of snow may be entrained on the path. In addition, the model according to equation (4) is dependent on the volume estimate. Therefore, for very first estimates, it may be feasible to apply an empirically found minimum angle of reach. A combination with equations (4) and (5) can be considered if a reasonable volume estimate is at hand.

The confinement model now includes data on the angle of reach of 28 rock-fall events that occurred in glacial environment. By including more events, equations (4) and (5) could be further refined. Additionally, testing the model on other events than the three case studies is necessary to contribute to the confidence in the model.

In any case, a first assessment on a regional scale only forms the starting point for more detailed investigations. Following a preliminary analysis as described above, it 
may be necessary to adopt a more detailed analysis at particularly sensitive locations using more sophisticated models. This may provide more information on the rock volume, snow or ice material involved or areas and structures potentially affected.

\section{Conclusions}

The modified single-flow direction algorithm proves robust and straightforward in propagating the flow of rock-ice avalanches downward. The reasonable simulations of the affected areas and run-out distances achieved in three case studies reveal the suitability of this flow/friction model for simulating rock-ice avalanches on a regional scale for initial broad-scale characterization. General flow patterns as well as changes in the direction of progression are reproduced in a realistic way and show that a topography-based flow-routing model simulates major rock-ice avalanches. A complete modelling procedure within a GIS environment facilitates model handling and application. The main restriction of the model, however, is the limitation of the avalanche motion to downward flow only. Thus, upward motion related to obstacles such as opposite wall obstruction cannot be simulated.

The empirical regression (4) for calculating run-out distances based on the statistical relation of avalanche volume and angle of reach suits the case studies presented. The worst-case scenario to cover all historically known cases based on the shifted regression between volume and angle of reach [equation (5)] may often overestimate real maximum run-out distances in the European Alps, but is likely a good means to obtain conservative estimates of potential maximum run-out distances. Nevertheless, in most cases, information on the volume involved is missing, and the regression model is sensitive to changes in volume. Therefore, the most robust and simple stop condition provides an empirical minimum of the angle of reach.

\section{Acknowledgements}

We would like to thank Andreas Kääb and Bernhard Krummenacher for support and continuous discussions and Stephan Gruber for careful comments on the manuscript. We are also indebted to Roland Lüthi for proof-reading the text and to Hubert Rehrauer for assistance in photographing. Furthermore, constructive and careful comments by two anonymous reviewers are gratefully acknowledged. Part of this study was supported by the Swiss National Science Foundation, as part of the NF21-59045.99 project.

\section{References}

[1] W. Haeberli, M. Wegmann and D. Vonder Mühll, Slope stability problems related to glacier shrinkage and permafrost degradation in the Alps, Eclogae Geol. Helv. 90 (1997) 407-414. 
[2] W. Haeberli and M. Beniston, Climate change and its impacts on glaciers and permafrost in the Alps, in: AMBIO - A Journal of the Human Environment, eds. A. Rapp and E. Kessler (The Royal Swedish Academy of Sciences, 1998) pp. 258-265.

[3] S. Gruber, M. Hoelzle and W. Haeberli, Permafrost thaw and destabilization of Alpine rock walls in the hot summer of 2003, Geophys. Res. Lett. 31(L13504) (2004) doi:10.1029/2004GL0250051.

[4] P. Deline, Recent Brenva rock avalanches (Valley of Aosta): new chapter in an old story? Geogr. Fis. Din. Quat. (2001) 55-63.

[5] S.G. Evans and J.J. Clague, Catastrophic rock avalanches in glacial environment, in: Proceedings of the Fifth International Symposium on Landslides, Lausanne, Switzerland, July 10-15 (1988).

[6] M. Zimmermann, P. Mani and H. Romang, Magnitude frequency aspects of alpine debris flows, Eclogae Geol. Helv. 90 (1997) 415-420.

[7] G. Meissl, Modelling the runout distances of rockfalls using a geographic information system, Z. Geomorphol. 125 (2001) 129-137.

[8] C. Harris, M.C.R. Davies and B. Etzelmüller, The assessment of potential geotechnical hazards associated with mountain permafrost in a warming global climate, Permafr. Periglac. Process. 12(1) (2001) 145-156.

[9] L.K.A. Dorren, Mountain Geoecosystems - GIS Modelling of Rockfall and Protection Forest Structure (University of Amsterdam, Amsterdam, 2002).

[10] N. Salzmann, A. Kääb, C. Huggel, B. Allgöwer and W. Haeberli, Assessment of hazard potential of ice avalanches using remote sensing and GIS-modelling, Nor. Geogr. Tidsskr. 58 (2004) 74-84.

[11] J. Noetzli, M. Hoelzle and W. Haeberli, Mountain permafrost and recent Alpine rock-fall events: a GIS-based approach to determine critical factors, in: Proceeding of the 8th International Conference on Permafrost, Zürich, Switzerland, 2003, eds. M. Philipps et al. (2003) pp. 827-832.

[12] F. Dutto and G. Mortara, Grandi frane storiche con percorso su ghiacciaio in Valle d'Aosta, Rev. Valdôtaine Hist. Nat. 45 (1991) 21-35.

[13] S.C. Porter and G. Orombelli, Catastrophic rockfall of September 12, 1717 on the Italian flank of the Mont Blanc Massif, Z. Geomorphol. 24(200-218) (1980).

[14] J.C. Alean, Untersuchungen über Entstehungsbedingungen und Reichweiten von Eislawinen, Versuchsanstalt für Wasserbau, Hydrologie und Glaziologie der ETH Zürich (1984).

[15] J. Coaz, Statistik und Verbau der Lawinen in Schweizeralpen (Stämpfli, Bern, Switzerland, 1910).

[16] G. Barla, F. Dutto and G. Mortara, Brenva Glacier rock avalanche of 18 January 1997 on the Mont Blanc range, Northwest Italy, Landslide News 13(2-5) (2000).

[17] R.J.E. Brown and T.L. Péwé, Distribution of permafrost in North America and its relationship to the environment, a review 1963-1973, in: Proceedings of the 2nd International Conference on Permafrost, Yakutsk, USSR, 1973, ed. National Academy of Sciences, Washington DC (1973).

[18] C. Harris, D. Vonder Mühll, K. Isaksen, W. Haeberli, J.L. Sollid, L. King, P. Holmlund, F. Dramis, M. Guglielmin and D. Palacios, Warming permafrost in European mountains, Glob. Planet. Change 39 (2003) 215-225.

[19] L.K.A. Dorren, A review of rockfall mechanics and modelling approaches, Prog. Phys. Geogr. 27(1) (2003) 69-87.

[20] G.F. Wieczorek and S. Jäger, Triggering mechanisms and depositional rates of postglacial slopemovement processes in the Yosemite Valley, California, Geomorphology 15 (1996) 17-31.

[21] V.J. Lunardini, Climatic warming and the degradation of warm permafrost, Permafr. Periglac. Process. 7 (1996) 311-320.

[22] C. Schaer, P.L. Vidale, D. Lüthi, C. Frei, C. Häberli, M.A. Liniger and C. Appenzeller, The role of increasing temperature variability in European summer heatwaves, Nature 427 (2003) 332-336.

[23] M.C.R. Davies, O. Hamza and C. Harris, The effect of rise in mean annual temperature on the stability of rock slopes containing ice-filled discontinuities, Permafr. Periglac. Process. 12(1) (2001) 137-144.

[24] S. Engemann, H. Reichert, H. Dosch, J. Bilgram, V. Honkimäki and A. Snigrev, Interfacial melting of ice in contact with $\mathrm{SiO}_{2}$, Phys. Rev. Lett. 92(20) (2004) 205701-1-205701-4. 
[25] S. Gruber, M. Peter, M. Hoelzle, I. Woodhatch and W. Haeberli, Surface temperatures in steep alpine rock faces - a strategy for regional-scale measurement and modelling, in: 8th International Conference on Permafrost, Proceedings, Zürich, Swets \& Zeitlinger, Lisse (2003).

[26] S. Gruber, M. Hoelzle and W. Haeberli, Rock wall temperatures in the Alps: modelling their topographic distribution and regional differences, Permafr. Periglac. Process. 15(3) (2004) 299-307.

[27] C. Huggel, W. Haeberli, A. Kääb, D. Bieri and S. Richardson, An assessment procedure for glacial hazards in the Swiss Alps, Can. Geotech. J. 41(6) (2004) 1068-1083.

[28] A. Kääb, R. Wessels, W. Haeberli, C. Huggel, J.S. Kargel and S.J.S. Khalsa, Rapid ASTER imaging facilitates timely assessment of glacier hazards and disasters, EOS 13(84) (2003) 117-124.

[29] V.M. Kotlyakov, O.V. Rotoaeva and G.A. Nosenko, The September 2002 Kolka glacier catastrophe in North Osetia, Russian Federation: evidence and analysis, Mt. Res. Dev. 24(1) (2004) 78-83.

[30] C. Huggel, S. Oswald, W. Haeberli, A. Kääb, A. Polkvoj, I. Galushkin and S.G. Evans, The 2002 rock/ice avalanche at Kolka/Karmadon, Russian Caucasus: assessment of extraordinary avalanche formation and mobility, and application of QuickBird satellite imagery, Nat. Hazards Earth Syst. Sci. 5(2) (2005) 173-187.

[31] Swisstopo, DHM25, Das digitale Höhenmodell der Schweiz, Level 2 (Bundesamt für Landestopographie, Wabern, Switzerland, 2002).

[32] S.K. Jenson and J.O. Domingue, Extracting topographic structure from digital elevation data for geographic information system analysis, Photogramm. Eng. Remote Sensing 54 (1988) $1593-1600$.

[33] C. Huggel, A. Kääb, W. Haeberli and B. Krummenacher, Regional-scale GIS-models for assessment of hazards from glacier lake outbursts: evaluation and application in the Swiss Alps, Nat. Hazards Earth Syst. Sci. 3(6) (2003) 647-662.

[34] P.J.J. Desmet and G. Govers, Comparison of routing algorithms for digital elevation models and their implications for predicting ephemeral gullies, Int. J. Geogr. Inf. Sci. 10(3) (1996) $311-331$.

[35] D.G. Tarboton, A new method for the determination of flow directions and upslope areas in grid digital elevation models, Water Resour. Res. 33(2) (1997) 309-319.

[36] L. Liang and D.S. MacKay, A general model of watershed extraction and representation using globally optimal flow paths and up-slope contributing areas, Int. J. Geogr. Inf. Sci. 14(4) (2000) 337-358.

[37] R.M. Iverson, S.P. Schilling and J.W. Vallance, Objective delineation of lahar-inundation hazard zones, Geol. Surv. Am. Bull. 110(8) (1998) 972-984.

[38] J.F. O'Callaghan and D.M. Mark, The extraction of drainage networks from digital elevation data, Comput. Vis. Graph. Image Process. 28 (1984) 323-344.

[39] L.W. Martz and J. Garbrecht, Numerical definition of drainage network and subcatchment areas from digital elevation models, Comput. Geosci. 18(6) (1992) 747-761.

[40] A. Heim, Bergstürze und Menschenleben, Beiblatt zur Vierteljahresschrift der Naturforschenden Gesellschaft in Zürich (1932).

[41] J. Corominas, The angle of reach as a mobility index for small and large landslides, Can. Geotech. J. 33 (1996) 260-271.

[42] S.G. Evans and O. Hungr, The assessment of rockfall hazard at the base of talus slopes, Can. Geotech. J. 26(427-446) (1993).

[43] R. Toppe, Terrain models - a tool for natural hazard mapping, in: Avalanche Formation, Movement and Effects, eds. B. Salm and H. Gubler (IAHS Publication, 1987) pp. 629-638.

[44] J. Alean, Ice avalanche activity and mass balance of high-altitude hanging glaciers in the Swiss Alps, Ann. Glaciol. 6 (1985) 248-249.

[45] A.E. Scheidegger, On the prediction of the reach and velocity of catastrophic landslides, Rock Mech. 5 (1973) 231-236. 
[46] K.J. Hsü, Catastrophic debris streams (Sturzstroms) generated by rockfalls, Geol. Soc. Am., Bull. 86 (1975) 129-140.

[47] L. Tianchi, A mathematical model for predicting the extent of a major rockfall, Z. Geomorphol. 27(4) (1983) 473-482.

[48] G. Bottino, M. Chiarle, A. Joly and G. Mortara, Modelling rock avalanches and their relation to permafrost degradation in glacial environments, Permafr. Periglac. Process. 13 (2002) 283-288.

[49] G. Plafker and F.E. Ericksen, Nevados Huascaran avalanches, Peru, in: Rockslides and Avalanches, Natural Phenomena, ed. B. Voight (Elsevier, Amsterdam, 1978) pp. 277-314.

[50] F. Dramis, M. Govi, M. Guglielmin and G. Mortara, Mountain permafrost and slope instability in the Italian Alps: the Val Pola landslide, Permafr. Periglac. Process. 6(1) (1995) 73-82.

[51] A. Hauser, Rock avalanche and resulting debris flow in Estero Parraguirre and Rio Colorado, Region Metropolitana, Chile, Rev. Eng. Geol. V (2002) 135-148.

[52] W. Haeberli, C. Huggel, A. Kääb, A. Polkvoj, I. Zotikov and N. Osokin, Permafrost conditions in the starting zone of the Kolka-Karmadon rock/ice slide of 20 September 2002 in North Osetia (Russian Caucasus), in: Extended Abstracts of the 8th International Conference on Permafrost, Zürich, Switzerland, 2003, eds. W. Haeberli and D. Brandova (2003) pp. 49-50. 